\title{
Binge eating disorder in men. A review of the relevant variables in the literature
}

\author{
Héctor Julián Velázquez López,' Rosalía Vázquez Arévalo,' Juan Manuel Mancilla Díaz’
}

1 Proyecto de Investigación en Nutrición, Facultad de Estudios Superiores Iztacala. Universidad Nacional Autónoma de México, Estado de México, México.

\section{Correspondence:}

Héctor Julián Velázquez López Proyecto de Investigación en Nutrición, Facultad de Estudios Superiores Iztacala. Universidad Nacional Autónoma de México.

Av. de los Barrios No. 1, Colonia Los Reyes Iztacala, C.P. 54090 Estado de México, México.

Phone: 5623 - 1333 Ext. 39736 and 39737

Email: hjv1402022187@hotmail.com

Received: 27 February 2017

Accepted: 28 February 2018

Citation:

Velázquez López, H. J., Vázquez Arévalo, R., Mancilla Díaz, J. M. Binge eating disorder in men. A review of the relevant variables in the literature. Salud Mental, $47(2), 91-100$. doi: 10.17711/SM.0185-3325.2018.014

\section{(c) (i) $(5)$}

\begin{abstract}
Background. Although binge eating disorder (BED) formally appeared in the fourth edition of the Diagnostic and Statistical Manual of Mental Disorders (DSM-IV), after nearly two decades of research, it is still considered understudied in men. Objective. To carry out a literature review with the variables that have been relevant in research on BED in men, from 1994 to 2015. Method. The article search was conducted in Medline and PsycINFO databases. Results. Twenty-eight articles were analyzed, none specifically investigated male population. Men engage less in restrictive dieting than women ( $29.8 \%$ and $57.3 \%$, respectively). Regarding body image, both men and women are prone to body dissatisfaction, although the ideal body is not necessarily the same. Regarding comorbidity, anxiety disorders are the most common ones in men with BED, in addition to the fact that they are more susceptible to substance abuse. Discussion and conclusion. Investigation on BED has mainly been conducted on female population, which suggests the need for more research on men that provides more empirical evidence.
\end{abstract}

Keywords: Binge eating disorder, feeding behavior, body image, anxiety, depression.

\section{RESUMEN}

Antecedentes. Aunque el trastorno por atracón (TPA) apareció en la cuarta versión del Manual Diagnóstico y Estadístico de los Trastornos Mentales (DSM-IV), después de casi dos décadas de investigación sigue sin ser muy estudiado en hombres. Objetivo. Realizar una revisión de la literatura de las variables relevantes en la investigación del TPA en hombres desde 1994 hasta el presente año. Método. Búsqueda sistemática en las bases de datos Medline y PsycINFO. Resultados. Se seleccionaron 28 artículos, de los cuales ninguno investigó específicamente a población masculina. Los hombres presentan menor frecuencia de dieta restrictiva en comparación con las mujeres ( $29.8 \%$ y $57.3 \%$, respectivamente). Respecto a la imagen corporal, tanto hombres como mujeres son propensos a presentar insatisfacción corporal, aunque el ideal corporal no necesariamente es similar. En cuanto a comorbilidad, en hombres con TPA, los trastornos de ansiedad son los más comunes, además de ser más propensos al abuso de sustancias. Discusión y conclusión. De los estudios analizados, ninguno se enfocó exclusivamente en población masculina, lo cual sugiere realizar mayor investigación en varones que proporcione evidencia empírica.

Palabras clave: Trastorno por atracón, conducta alimentaria, imagen corporal, ansiedad, depresión. 


\section{BACKGROUND}

In the fourth revised version of the Diagnostic and Statistical Manual of Mental Disorders (DSM-IV-TR), the American Psychiatric Association (2000) defines eating behavior disorders as those characterized by severe alterations in eating behavior, in other words, these disorders are due to a psychological alteration. The fifth edition of the Diagnostic and Statistical Manual of Mental Disorders (DSM5) (American Psychiatric Association, 2013) modifies the concept of what are now called eating and food intake disorders, defined as a persistent alteration in eating or eating behavior that leads to an alteration in the consumption or absorption of food that causes a significant deterioration of physical health or psychosocial functioning (American Psychiatric Association, 2013).

Another significant modification related to the classification of eating and food intake disorders is the recognition of binge eating disorder (BED) as comparable to anorexia and bulimia nervosa, in other words, it is no longer considered a diagnostic category for research. In order to clarify its clinical characteristics, with diagnostic criteria that are almost the same as those proposed in the DSM-IV (American Psychiatric Association, 1994) except for frequency (from twice a week to once a week) and the time lapse since the onset of binge eating (from 6 months to 3 months), which can be observed in the diagnostic criteria for BED according to the DSM-5 (American Psychiatric Association, 2013).

The background to BED lies in the research conducted by Stunkard (1959), in which he identified the presence of what he called "night eating syndrome", understood as episodes of consuming large amounts of food in a rapid, uncontrolled way until a point of physical discomfort is reached, followed by feelings of guilt, remorse, or self-loathing, without compensatory behaviors, followed by the restriction of food in the morning, all in obese patients under treatment for weight control. However, it was not until 1994 that the BED category formally appeared in the fourth version of the DSM-IV (American Psychiatric Association, 1994), proposed as a new diagnostic category for research (Appendix $\mathrm{B}$ of criteria and proposed lines of research for further studies).

Prevalence in community samples has been estimated at between 2\% and 6\% (Castro \& Ramírez, 2013; Hudson, Hiripi, Pope, \& Kessler, 2012; Litwack, Mitchell, Sloan, Reardon, \& Miller, 2014; Neumark-Sztainer, Sherwood, French, \& Jeffery, 1999; Spitzer et al., 1993). In clinical samples, which mainly include patients with obesity in treatment for weight control, there is a higher prevalence, ranging from 30\% to 54\% (Fitzgibbon, Sánchez-Johnsen, \& Martinovich, 2003; Gormally, Black, Datson, \& Rardin, 1982; Hsu et al., 2002; Johnsen, Gorin, Stone, \& Grange, 2003; Spitzer et al., 1992; Spitzer et al., 1993; Villagómez,
Cortés, Barrera, Saucedo, \& Alcocer, 2003; Williamson \& Martin, 1999).

Although not everyone with obesity has BED, most of the prevalence of this disorder is found in this population, which has prompted interest in studying the relationship between BED and obesity, since the body mass index (BMI) of individuals with BED ranges from 32 to 42, equivalent to type I obesity (BMI 30-34.9) and type III obesity (BMI > 40) (Ramacciotti et al., 2000; Spitzer et al., 1992; Spitzer et al., 1993; Vervaet, van Heeringen, \& Audenaert, 2004).

As for the age of onset, it has been estimated that BED occurs at around 32 (American Psychiatric Association, 2013, García-Camba, 2001, Marcus, 1997), showing that this disorder occurs in adulthood, unlike bulimia and anorexia nervosa, which usually appear in adolescence.

Another aspect to consider is that BED has mainly been studied in female population, despite being the most frequent eating disorder in men and occurring in similar proportions in both sexes (two cases of men for every three of women) (American Psychiatric Association, 2000; Castonguay, Eldredge, \& Agras, 1995; Hoek \& van Hoeken, 2003; Spitzer et al., 1993; Weltzin et al., 2005; Womble et al., 2001).

One possible problem in the detection of BED in men is that the intake of large amounts of food may be a common cultural feature for men, and therefore not considered abnormal behavior. There are also certain limitations on the diagnosis of BED, among which the fact that certain professionals and those with this condition do not consider that eating and food intake disorders can be present in men, which leads to an underestimation of both diagnosis and research on this disorder. This raises the following question: what variables have been relevant to BED research in the male population?

The study of BED in men makes it necessary to know the advances and limitations of the research that has considered them to date, as well as the variables studied in this regard. Accordingly, the purpose of this paper is to conduct a literature review of the variables that have been significant in research on BED in men, from 1994 to the present.

\section{METHOD}

Through a systematic search of articles in the Medline and PsycINFO databases, a total of 74 articles were found (26 from Medline and 48 from PsycINFO), 28 of which were used and 46 of which were ruled out on the basis of the following inclusion and exclusion criteria.

\section{Inclusion criteria}

1. BED is the central theme of the research, in other words, the articles address this topic as the main axis of study. 
2. It considers the male population.

3. The articles are written in English or Spanish, and

4. BED is addressed using the diagnostic criteria of the DSM-IV (American Psychiatric Association, 1994) and DSM-5 (American Psychiatric Association, 2013).

\section{Exclusion criteria}

1. Articles focus on treatment and/or therapy.

2. Case studies or theoretical reviews.

3. Articles only evaluate the psychometric properties of instruments, and

4. Articles focus on evaluating the implication of BED in surgical procedures.

The following articles were ruled out for the present paper: 15 articles (seven from Medline and eight from PsycINFO) that did not feature BED as a central theme of the research, 11 articles (seven from Medline and four from PsycINFO) that focused on treatment and/or therapy, five reviews (from PsycINFO), six articles (three from Medline and three from PsycINFO) that only considered female population, six articles (three from Medline and three from PsycINFO) that focused on analyzing the psychometric properties of instru- ments, and three articles (from Medline) that focused on evaluating the implication of BED in surgical procedures.

\section{Procedure}

A systematic search of articles from scientific journals was carried out in February 2015 through the Medline and PsycINFO databases, using the following English keywords: "Binge Eating Disorder", "Binge-Eating Disorder", "Obesity", "male" and "men", which should appear in the title, abstract, and keywords of the articles. The period when the articles were evaluated was from 1994 to the present.

An analysis of the articles considered in the present review was carried out according to the criteria established by Cororve and Gleaves (2004), which consider the analysis of the main purpose of the study, sample characteristics, results obtained, main conclusions, and references.

Subsequently, a group of experts was contacted in the area of eating and food intake disorders to complement the correct selection of the articles to be analyzed.

It should be noted that the search for articles failed to yield a single text specifically designed to assess BED in the male population. Thus, part of the information presented in

Table 1

Sociodemographic characteristics of samples in selected articles

\begin{tabular}{|c|c|c|c|c|c|}
\hline \multirow[b]{2}{*}{ Reference } & \multirow[b]{2}{*}{ Type of sample } & \multicolumn{2}{|c|}{ Distribution by gender } & \multicolumn{2}{|c|}{ Age } \\
\hline & & Men & Women & $(\overline{\mathrm{X}} \pm S D)$ & Range \\
\hline Amianto et al. (2011) & Clinical & $43.8 \%$ & $57.2 \%$ & $42.5 \pm 12.5$ & ---- \\
\hline Barry et al. (2002) & Clinical & $19.2 \%$ & $80.7 \%$ & $42.3 \pm 9.5$ & $21-61$ \\
\hline Cuzzolaro et al. (2008) & Clinical & $44.0 \%$ & $55.9 \%$ & $36.3 \pm 10.8$ & --- \\
\hline Galanti et al. (2007) & Clinical & $30.1 \%$ & $69.8 \%$ & $40.0 \pm 10.0$ & $20-60$ \\
\hline Geliebter et al. (2001) & Clinical & $28.2 \%$ & $71.7 \%$ & $42.0 \pm 10.0$ & $23-62$ \\
\hline Grilo \& Masheb (2004) & Clinical & $21.7 \%$ & $78.3 \%$ & $44.4 \pm 9.3$ & $20-60$ \\
\hline Grilo \& Masheb (2005) & Clinical & $22.1 \%$ & $77.8 \%$ & $24.0 \pm 9.1$ & $21-65$ \\
\hline Grilo et al. (2009) & Clinical & $23.2 \%$ & $76.7 \%$ & $44.9 \pm 9.0$ & ----- \\
\hline Hrabosky et al. (2007) & Clinical & $27.1 \%$ & $72.8 \%$ & $38.2 \pm 5.7$ & ----- \\
\hline Kolotkin et al. (2004) & Clinical & $40.1 \%$ & $59.8 \%$ & $48.9 \pm 14.1$ & ---- \\
\hline Linde et al. (2004) & Clinical & $28.1 \%$ & $71.8 \%$ & $50.7 \pm 12.0$ & ---- \\
\hline Lundgren et al. (2010) & Clinical & $39.7 \%$ & $60.3 \%$ & $43.9 \pm 10.4$ & ---- \\
\hline Masheb and Grilo (2006a) & Clinical & $26.5 \%$ & $73.4 \%$ & $45.2 \pm 8.8$ & $18-59$ \\
\hline Masheb and Grilo (2006b) & Clinical & $21.8 \%$ & $78.1 \%$ & $45.2 \pm 8.8$ & ---- \\
\hline Reas \& Grilo (2007) & Clinical & $25.7 \%$ & $74.2 \%$ & $45.1 \pm 9.4$ & ---- \\
\hline Reas et al. (2004) & Clinical & $23.3 \%$ & $76.6 \%$ & $44.2 \pm 9.2$ & --- \\
\hline Reas et al. (2005) & Clinical & $21.2 \%$ & $78.7 \%$ & $44.7 \pm 8.9$ & - \\
\hline Roehrig et al. (2009) & Clinical & $27.5 \%$ & $72.4 \%$ & $44.5 \pm 9.4$ & $18-59$ \\
\hline Colles et al. (2008) & $\begin{array}{l}\text { Clinical and } \\
\text { community }\end{array}$ & $18.7 \%$ & $81.2 \%$ & $45.8 \pm 13.3$ & $18-70$ \\
\hline Feldman \& Meyer (2007) & Community & $50.0 \%$ & $50.0 \%$ & $32.0 \pm 9.0$ & $18-59$ \\
\hline Feldman \& Meyer (2010) & Community & $49.7 \%$ & $50.2 \%$ & $33.0 \pm 9.0$ & ---- \\
\hline Grucza et al. (2007) & Community & $45.0 \%$ & $55.0 \%$ & $44.0 \pm 14.0$ & ---- \\
\hline Hay (1998) & Community & $40.0 \%$ & $60.0 \%$ & $46.0 \pm 19.0$ & $15-94$ \\
\hline Hodges et al. (1999) & Community & $64.0 \%$ & $35.5 \%$ & $22.3 \pm 5.0$ & --- \\
\hline Neumark-Sztainer et al. (2009) & Community & $44.9 \%$ & $55.0 \%$ & $14.3 \pm .8$ & ----- \\
\hline Nicdao et al. (2007) & Community & $47.6 \%$ & $52.4 \%$ & --- & $\geq 18$ \\
\hline Striegel-Moore et al. (1998) & Community & $45.6 \%$ & $54.4 \%$ & $46.8 \pm 10.7$ & ---- \\
\hline Tanofsky (1997) & Community & $50.0 \%$ & $50.0 \%$ & $41.4 \pm 8.0$ & \\
\hline
\end{tabular}

Note: $\bar{X}=$ mean; $\pm S D=$ Standard deviation. 
the results section was compiled on the basis of the female population, provided it offered evidence that would contribute to characterizing possible relevant aspects of BED in the male population.

\section{RESULTS}

\section{Origin of articles}

The articles analyzed were mainly from the United States, with 24 articles, followed by Italy with two articles, and finally Australia with two articles.

\section{Characteristics of respondents}

In the 28 selected articles, a purposive, non-probabilistic sampling was used, including nine with community samples, 18 with clinical samples and one with a clinical community sample. This shows that much of the research on BED is conducted on populations of patients with obesity in weight loss programs.

Regarding the sex of the participants, although it has been mentioned that BED is the most frequent eating disorder in men (Hoek \& van Hoeken, 2003; Weltzin et al., 2005), in the studies reviewed, none were found that specifically focused on analyzing this population, and in those that did include male respondents, the percentage was lower in most articles ( 25 out of 28 articles) (Table 1), which shows a lack of inclusion of this population in BED studies which hampers better understanding of this disorder in the male population.

Respondents were 14-94 years, with an average age of 14.3 to 50.7 years. In most research, the average age is between 42 and 45 (Table 1). While it is true that some studies have mentioned that BED is an eating and food intake dis- order that occurs mainly in adulthood (American Psychiatric Association, 2013; Garcia-Camba, 2001; Marcus, 1997), the lack of studies and specificity regarding the characteristics of male respondents with a BED diagnosis requires further research on this disorder so as to have more detailed information on the characteristics of men with BED, since most studies on male population explain BED characteristics in a general way without specifically describing each gender.

\section{Epidemiology and prevalence}

Of the 28 articles, six analyzed the prevalence of BED, five in a community sample and one in a clinical sample.

In the community samples in the articles reviewed, prevalence rates in men range from $1.5 \%$ to $6.8 \%$ (Feldman \& Meyer, 2007; Grucza, Przybeck, \& Cloninger, 2007; Hay, 1998; Hodges, Stellefson, Jarrell, Cochrane, \& Brewerton, 1999; Nicdao, Hong, \& Takeuchi, 2007). The comparison between genders shows a higher prevalence in women. As for the clinical sample, in patients with obesity who attend treatment for weight reduction (Lundgren, Rempfer, Brown, Goetz, \& Hamera, 2010), a higher prevalence of BED was found than in the community sample (5.9\%) for both genders together since the prevalence for each gender is not specified (Table 2). Regarding partial BED, there is a higher prevalence of this syndrome in men (Feldman \& Meyer, 2007).

Sexual orientation (homosexuals and bisexuals) is an aspect that possibly increases the prevalence of BED, both in men $(5.2 \%$ in homosexuals and bisexuals and $1.5 \%$ in heterosexuals) and women (4.6\% in homosexuals and bisexuals and $1.6 \%$ in heterosexuals) (Feldman \& Meyer, 2007). However, there is a lack of empirical evidence to confirm these findings, since only one article evaluated this characteristic. In addition, the authors report that no statis-

Table 2

Studies of BED prevalence in men

\begin{tabular}{|c|c|c|c|}
\hline & Sample & Type of sample & Percentage of BED in men \\
\hline Feldman \& Meyer (2007) & $\begin{array}{l}128 \text { heterosexuals } \\
\text { (65 men and } 63 \text { women) } \\
\text { and } 388 \text { Lesbians, Gays and Bisexuals } \\
\text { (193 men and } 195 \text { women) }\end{array}$ & Community & $\begin{array}{c}\text { Gays and Bisexuals } 5.2 \% \\
1.5 \% \text { heterosexuals }\end{array}$ \\
\hline Grucza et al. (2007) & $\begin{array}{l}910 \text { respondents } \\
\text { ( } 411 \text { men and } 499 \text { women) }\end{array}$ & Community & $6.8 \%$ \\
\hline Hay (1998) & $\begin{array}{l}3001 \text { respondents } \\
\text { (1216 men and } 1785 \text { women) }\end{array}$ & Community & $1.0 \%$ \\
\hline Hodges et al. (1999) & $\begin{array}{l}411 \text { respondents } \\
\text { ( } 265 \text { men and } 146 \text { women) }\end{array}$ & Community & $1.9 \%$ \\
\hline Lundgren et al. (2010) & $\begin{array}{l}68 \text { people attempting to lose weight } \\
\text { ( } 27 \text { men and } 41 \text { women) }\end{array}$ & Clinical & $5.9 \%$ for the total sample \\
\hline Nicdao et al. (2007) & $\begin{array}{l}2095 \text { respondents } \\
\text { (998 men and } 1097 \text { women) }\end{array}$ & Community & $1.3 \%$ \\
\hline
\end{tabular}

Note: BED = Binge Eating Disorder. 
tically significant differences were found in the prevalence of BED with respect to sexual orientation in men $(O R=3.5$ $95 \% \mathrm{CI}=[.4,28])$.

\section{Body mass index (BMI)}

Although it has been established that BED is frequently associated with overweight or obesity, in the case of the present review, only 20 articles considered the body mass index (BMI) of their respondents, where those with BED, both men and women, had BMI averages of 32 to 42 . Specifically in men, the average BMI ranged from 34 to 41 , which is equivalent to type I (BMI 30 - 34.9) to type III (BMI > 40) obesity (Table 3 ).

\section{Relevant factors in BED research}

A broad range of variables involving BED are explored. However, some refer to the same meaning but with a different name, as in the case of food disinhibition and binge eating, which refer to an excessive intake of food accompanied by a loss of control over eating or, on the other hand, to the cognitive restriction and the restrictive diet oriented towards the avoidance of foods with the aim of preventing weight gain. These aspects highlight the importance of having clarity when considering different aspects of this problem, in order not to create confusion when interpreting the results.
In this paper, data were classified into three axes based on the aspects that have been relevant in research on eating and food intake disorders: 1 . eating behavior, 2 . body image, and 3 . comorbidity and symptomatology of anxiety and depression.

\section{Eating behavior}

A restrictive diet, both in men and women, is more common in: 1 . those people with obesity who wish to lose weight for reasons of appearance as opposed to those who wish to lose weight for health reasons (Reas, Masheb, \& Grilo, 2004); 2. in obese people with BED who attend support groups for weight loss (Colles, Dixon, \& O'Brien, 2008); 3. in those who have had a restrictive diet before being overweight and/or bingeing compared to those who were first overweight or binged (Reas \& Grilo, 2007); and 4. in people who are obese at an earlier age.

Regarding the food behavior associated with BED, there are several clinically relevant characteristics. A restrictive diet is the most commonly evaluated aspect, although it has been shown that only $29.8 \%$ of men follow one or less frequently in comparison with women (57.3\%), which indicates that it is not a weight loss strategy for most men with BED (Barry, Grilo, \& Masheb, 2002; Grilo \& Masheb, 2004; Roehrig, Masheb, White, \& Grilo, 2009; Tanofsky, Wilfley, Spurrell, Welch, \& Brownell, 1997).

Eating patterns in individuals with BED is an under-researched aspect, since only one article addressed this topic

Table 3

$B M I$ Averages in respondents in the studies analyzed

\begin{tabular}{|c|c|c|c|}
\hline \multirow[b]{3}{*}{ Reference } & \multicolumn{2}{|c|}{$\begin{array}{l}\text { BMI } \\
\text { BED }\end{array}$} & \multirow[b]{2}{*}{ Total } \\
\hline & Men & Women & \\
\hline & $(\overline{\mathrm{X}} \pm S D)$ & $(\bar{X} \pm S D)$ & $(\overline{\mathrm{X}} \pm S D)$ \\
\hline Nicdao et al. (2007) & ---- & ---- & $36.6 \pm 4.9$ \\
\hline Barry et al. (2002) & $40.7 \pm 9.1$ & $35.6 \pm 8.1$ & $38.1 \pm 8.6$ \\
\hline Colles et al. (2008) & ----- & ----- & $32.7 \pm 7.3$ \\
\hline Cuzzolaro et al. (2008) & $40.4 \pm 9.4$ & $35.2 \pm 8.1$ & $36.4 \pm 8.6$ \\
\hline Galanti et al. (2007) & ----- & ----- & $39.6 \pm 7.2$ \\
\hline Geliebter et al. (2001) & $37.4 \pm 6.9$ & $38.5 \pm 10.3$ & $38.0 \pm 9.4$ \\
\hline Grilo \& Masheb (2004) & $37.1 \pm 6.9$ & $35.7 \pm 8.4$ & $35.3 \pm 7.8$ \\
\hline Grilo \& Masheb (2005) & $40.4 \pm 9.4$ & $35.2 \pm 8.1$ & $36.4 \pm 8.6$ \\
\hline Grilo et al. (2009) & ----- & ----- & $37.1 \pm 7.1$ \\
\hline Hrabosky et al. (2007) & ----- & ----- & $38.2 \pm 5.7$ \\
\hline Kolotkin et al. (2004) & $41.3 \pm 11.1$ & $37.6 \pm 9.6$ & $42.0 \pm 10.4$ \\
\hline Linde et al. (2004) & $33.1 \pm 4.5$ & $33.8 \pm 6.0$ & $34.2 \pm 5.2$ \\
\hline Masheb \& Grilo (2006a) & ----- & ----- & $37.9 \pm 5.6$ \\
\hline Masheb \& Grilo (2006b) & ----- & ----- & $36.4 \pm 6.8$ \\
\hline Neumark-Sztainer et al. (2009) & $34.5 \pm 6.9$ & $32.3 \pm 5.6$ & $33.4 \pm 6.2$ \\
\hline Reas \& Grilo (2007) & ----- & ----- & $37.5 \pm 6.8$ \\
\hline Reas et al. (2004) & ----- & ----- & $37.1 \pm 8.4$ \\
\hline Reas et al. (2005) & ----- & ----- & $37.5 \pm 7.3$ \\
\hline Roehrig et al. (2009) & $38.2 \pm 6.0$ & $37.9 \pm 6.5$ & $37.9 \pm 6.2$ \\
\hline Tanofsky et al. (1997) & $38.7 \pm 3.5$ & $37.6 \pm 5.5$ & $38.1 \pm 4.5$ \\
\hline
\end{tabular}

Note: $\overline{\mathrm{X}}=$ mean $; \pm S D=$ Standard deviation. 
(Masheb \& Grilo, 2006a). This shows that most individuals with BED (67.6\%) do not have regular eating habits, since only $32.4 \%$ eat three meals a day (breakfast, lunch, and dinner), which are associated with lower body weight and less bingeing behavior. It was also found that breakfast (42.8\%) is consumed less frequently than lunch $(64.2 \%)$ or dinner $(83.2 \%)$, in other words, fasting is common in this population.

On the other hand, concern over food is more common among those who follow restrictive diets, want to lose weight for aesthetic reasons, and those in whom obesity precedes restrictive diets and binge eating behaviors (Masheb \& Grilo, 2006a; Reas et al., 2004; Reas \& Grilo, 2007). Regarding gender differences, men express less concern over food than women (Barry et al., 2002; Roehrig et al., 2009).

Finally, and given that the roots of BED lie in the "night eating syndrome" (Stunkard, 1959), this characteristic is frequently explored. However, in the present review, only one study of this aspect was found, in which most patients with obesity with BED (71.98\%) do not engage in this behavior, while those who do $(28.01 \%)$ have a higher BMI and it is more common in men $(42 \%)$ than women $(24 \%)$ (Grilo \& Masheb, 2004).

\section{Body image}

When talking about eating and food intake disorders, body image and its implications are considered relevant issues, since they may influence various aspects, such as eating behavior, weight control methods and mood, among others. However, it should be clarified that this is not required for a BED diagnosis.

With respect to the articles reviewed, nine of the 28 articles evaluated the body image in relation to BED, proposing that there are several factors that contribute to the idealization of body image and its distortion in men (Leit, Gray, \& Pope, 2002), including cultural changes that lead to unrealistic expectations of the male body image (Brownell \& Napolitano, 1995; Leit et al., 2002), something which, unlike women, does not necessarily imply an ideal of thinness (Anderson, 1999). In the articles that considered evaluating body image, it was found that both men and women are prone to experience body dissatisfaction (Anderson, 1999). However, it is worth noting that there is controversy about whether men care about body image as much as women (Edwards \& Launder, 2000), which would be a point to discuss in the case of men, since, as mentioned previously, not everyone seeks a bodily ideal similar to that of women. Moreover, in the case of BED in men, research usually focuses on the analysis of levels of body dissatisfaction rather than on the ideal body shape they would like to achieve.

Two relevant characteristics in research on eating and food intake disorders are concern over weight and body image. In the case of BED in the male population in the articles reviewed, it is also possible to identify this perception, in addition to the fact that they are the most commonly evaluated body image variables, which show that men with BED express greater concern over weight and body image than those without it. However, a comparison of men and women shows that men have lower levels of these characteristics than women (Barry et al., 2002; Cuzzolaro, Donini, Bellini, \& Santomassimo, 2008; Grilo \& Masheb, 2004; Grilo \& Masheb, 2005; Roehrig et al., 2009; Tanofsky et al., 1997).

It should be noted that concern with body image, in both men and women, occurs more frequently on the basis of the following characteristics: 1 . in those who wish to lose weight for aesthetic rather than health reasons (Reas et al., 2004); 2 . in those who are overweight first, rather than those who engaged in a restrictive diet and/or binge eating first (Reas \& Grilo, 2007); and 3. in those who practice night eating compared with those who do not (Grilo \& Masheb, 2004).

Some behaviors associated with concern for weight and body image, which occur in more than half the people with BED (57.4\%), involve checking body areas, in other words, constantly checking their bodies looking for fat, in addition to avoiding wearing clothes that make them aware of the shape of their bodies, which are related to a greater frequency of binge eating, food disinhibition, restrictive diet, and over-estimation of body size (Reas, Grilo, Masheb, \& Wilson, 2005).

Lastly, it is necessary to mention that the reasons for losing weight influence the levels of concern over weight and body image, since those who want to lose weight for aesthetic reasons are more concerned with their weight than those who wish to lose weight for health reasons. At the same time, the reasons for this loss are similar between the two sexes $(72.4 \%$ of men and $61.6 \%$ of women do so for health reasons) (Reas et al., 2004).

\section{Comorbidity with anxiety and depression}

In the present review, only three articles evaluated comorbidity with Axis 1 disorders in the DSM-IV-TR (American Psychiatric Association, 2000) based on a diagnostic interview (Structured Clinical Interview for DSM Axis I Disorders (SCID-I/P) (First, Spitzer, Gibbon, \& Williams, 1996), which found that between $46 \%$ and $48 \%$ of those with BED (both men and women) have at least one psychiatric disorder, the most frequent of which were anxiety disorders ( $27 \%$ to $43 \%$ ), particularly specific phobia (Grilo, White, \& Masheb, 2009; Feldman \& Meyer, 2010). At the same time, mood disorders occur in between $20 \%$ and $24.5 \%$ of men, with major depressive disorder occurring most frequently (Grilo et al., 2009; Feldman \& Meyer, 2010) (Table 4).

\section{Anxiety and depression symptomatology}

Of the articles reviewed, 14 evaluated anxiety and depression symptomatology using self-report instruments, partic- 
Table 4

Articles assessing psychiatric comorbidity associated with BED

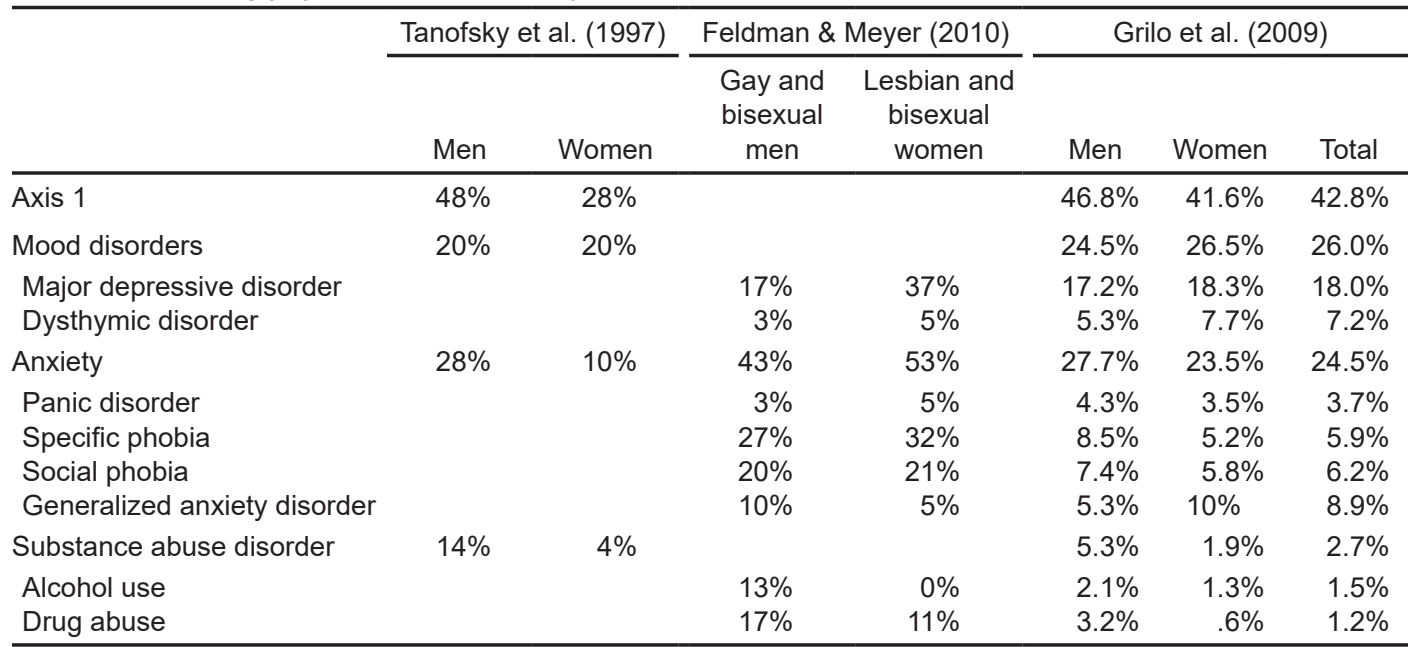

ularly the Beck Depression Inventory (Beck, 1976; Beck \& Steer, 1993) and the Beck Anxiety Inventory (Beck, Epstein, Brown, \& Steer, 1988). Regarding this symptomatology, Amianto et al. (2011) found that patients with obesity with BED (both men and women) had more depression and anxiety symptoms than those without BED (Galanti, Gluck, \& Geliebter, 2007; Geliebter, Hassid, \& Hashim, 2001; Kolotkin et al., 2004), which in turn is related to greater concern over food, weight, and body image, as well as lower self-esteem and poor quality of life (Kolotkin et al., 2004; Nicdao et al., 2007).

At the same time, substance abuse occurs in $2.7 \%$ of men and women with BED; in this sphere, alcohol and drug abuse were the most common forms of substance abuse $(1.5 \%$ and $1.2 \%$, respectively). Men are more likely to engage in some form of substance abuse than women (Grilo et al., 2009; Feldman \& Meyer, 2010), particularly drug dependence (Table 4).

Finally, it seems that sexual orientation could play a key role in substance use, since it was found that homosexual and bisexual men with BED seem to be more prone to engage in this, particularly alcohol and drug abuse (Feldman $\&$ Meyer, 2010). However, the evidence is still scarce since only one article included sexual orientation as a variable of analysis and no comparisons were made with heterosexual men.

\section{DISCUSSION AND CONCLUSION}

The objective of this study was to review the literature to determine the variables that have been relevant in the study of BED in men. In this field of research, this issue has made great strides since its inclusion in the DSM-IV (American Psychiatric Association, 1994). However, there are still many controversial aspects that must be explored in order to determine the clinical signs associated with this disorder, particularly with regard to the male population, since most research has been conducted on women. In the few studies that do include men, the data and analyses are not specific for each sex, despite the fact that this is the most frequent eating and food intake in this group (Hoek \& van Hoeken, 2003; Weltzin et al., 2005), which highlights the need to continue providing findings that complement the overview of BED in the male population.

Regarding the origin of the articles used in the review, those from the English-speaking world predominated. Most of them were from the United States of America, which reflects the enormous scientific production from that country, and points to the need to obtain data from other parts of the world, such as Latin America. Regarding the age of onset of BED, it is estimated to be approximately 32 (García-Camba, 2001; Marcus, 1997; Reas et al., 2004). In the articles reviewed, however, we observed that the average age of respondents was between 42 and 45 . This data provides evidence on the occurrence of this disorder mainly in adulthood, unlike anorexia and bulimia nervosa, which are more frequent during adolescence.

With respect to the study variables related to BED research, it was observed that eating behavior, body image, and anxiety and depression symptomatology are the aspects most frequently considered of this disorder, and these are addressed below. Regarding eating behavior, the adoption of a restrictive diet proved to be a fundamental aspect of BED, since it is related to the frequency of binge eating and the presence of obesity at an early age. In the case of the articles analyzed, it was observed that in the male population, the characteristics of a restrictive diet were poorly evaluated, especially in terms of their objectives and frequency. 
A similar case is found in relation to the analysis of eating patterns, since, although this was evaluated in the male population, showing that men do not engage in a regular pattern of eating and that fasting could be frequent, these results were only found in one study in the present review, meaning that they may not be conclusive. There are certain variables related to eating behavior that were not explored by any study, such as compensatory behaviors, eating habits, and emotional influences related to food intake, which have proved important in the study of BED in women.

As for body image, it is important to note that the evaluation of this feature is not required in a BED diagnosis. However, some researchers state the need to explore this aspect in greater depth, since it may be associated with the motivation to lose weight, following a restrictive diet and even the frequency of binge eating (Reas et al., 2004; Reas et al., 2005). One of the most commonly evaluated aspects in this area is the presence of body dissatisfaction. In the case of men, some studies (Anderson, 1999; Colles et al., 2008) indicate that they are susceptible to having body dissatisfaction. However, in the articles analyzed, there are no data showing their occurrence or association with variables important for BED.

At the same time, anxiety and depression are factors associated with the presence of binge eating, which is why they constitute key elements in the study of the BED. However, in the case of men there is insufficient evidence to obtain clear information on the comorbidity of these conditions in this population. In the present review, only three studies showed that men with BED had more depression and anxiety symptoms than those without it. It is therefore important to note that research of this symptom in relation to this disorder in men is still incipient, since its relationship with other variables that have been significant in studies on the female population, such as concern over food, weight, body image, and self-esteem, is not known (Bulick, Sullivan, \& Kendler, 2002; Kolotkin et al., 2004; Grilo et al., 2009; Robertson \& Palmer, 1997; Telch \& Agras, 1994).

As for sexual orientation, some authors have mentioned that there could be a greater proportion of homosexual and bisexual men (5.2\%) compared to heterosexuals (1.5\%). However, only one study was found in which a greater proportion of BED could be observed in homosexual than heterosexual men, in which the differences did not prove to be statistically significant (Feldman \& Meyer, 2010; Hefferman, 1994), as a result of which this result may not be conclusive.

The present review enabled us to highlight the bias of BED research on female population and the exploration of certain variables without taking into account the possible differences that may exist when considering the male population, such as body image and eating behaviors. Although it has been shown that men can also experience body dissatisfaction, little is known about the male population, since for a long time it was considered that this dissatisfaction mainly occurred in women, as a result of which this issue failed to be explored in men.

Lastly, regarding the comorbidity between BED and anxiety and depression, there is still a need to delve more deeply into its relationship with key variables in the study of BED that have yet to be explored in the male population, mainly with the frequency and severity of binge eating.

\section{Limitations}

The search procedure for articles indexed in specific databases only made it possible to include the articles contained in these indices. It is therefore suggested that search parameters should be expanded to other media, such as the indices of specialized journals that are not included in databases yet which could provide valuable information in future reviews.

\section{Funding}

This study was partly funded by the Program of Support for Research Projects and Technological Innovation (PAPIIT, No. IN305912).

\section{Conflict of interests}

The authors declare they have no conflict of interests.

\section{REFERENCES}

American Psychiatric Association (1994). Diagnostic and statistical manual of mental disorders (DSM-IV, Fourth Edition). Washington, D.C.: A.P.A. Press.

American Psychiatric Association (2000). Diagnostic and statistical manual of mental disorders (DSM-IV-TR, Fourth Revised Edition). Washington, D.C.: A.P.A. Press.

American Psychiatric Association (2013). Diagnostic and Statistical Manual of Mental Disorders (DSM-5). Washington, D.C.: A. P. A. Press.

Amianto, F., Lavagnino, L., Leombruni, P., Gastaldi, F., Daga, G. A., \& Fassino, S. (2011). Hypomania across the binge eating spectrum. A study on hypomanic symptoms in full criteria and sub-threshold binge eating subjects. Journal of Affective Disorders, 133(3), 580-583.

Anderson, A. E. (1999). Gender related aspects of eating disorders: A guide to practice. The Journal of Gender-Specific Medicine, 2(1), 47-54.

Barry, D. T., Grilo, C. M., \& Masheb, R. M. (2002). Gender differences in patients with binge eating disorder. International Journal of Eating Disorders, 31(1), 63-70.

Beck, A. T. \& Steer, R. A. (1993). Beck Depression Inventory. Manual. San Antonio, TX: The Psychological Corporation.

Beck, A. T. (1976). Depression: Clinical experimental and theoretical aspects. In H. Leitenberg (Ed.), Handbook of behavior modification and behavior therapy. New York: Prentice-Hall.

Beck, A. T., Epstein, N., Brown, G., \& Steer, R. (1988). An inventory for measuring clinical anxiety psychometric properties. Journal of Consulting and Clinical Psychology, 56(6), 893-897.

Brownell, K. D. \& Napolitano, M. A. (1995). Distorting Reality for Children: Body Size Proportions of Barbie and Ken Dolls. International Journal of Eating Disorders, 18(3), 295-298.

Bulick, C. M., Sullivan, P. F., \& Kendler, K. S. (2002). Medical and psychiatric morbidity in obese women with and without binge eating. International Journal of Eating Disorders, 32(1), 72-78.

Castonguay, L. G., Eldredge, K. L., \& Agras, W. S. (1995). Binge eating disorder: Current state and future directions. Clinical Psychology Review, 15(8), 865-890.

Castro, A. L. \& Ramírez, A. L. (2013). Prevalencia de manifestaciones del trastorno por atracón en adultos con sobrepeso y obesidad. Revista Costarricense de Salud Pública, 22(1), 20-26. 
Colles, S. L., Dixon, J. B., \& O'Brien, P. E. (2008). Loss of control is central to psychological disturbance associated with binge eating disorder. Obesity, 16(3), 608-614.

Cororve, F. M. \& Gleaves, D. H. (2004). Sociocultural, feminist, and psychological influences on women's body satisfaction: A structural modeling analysis. Psychology of Women Quarterly, 28(4), 370-380.

Cuzzolaro, M., Donini, L., Bellini, M., \& Santomassimo, C. (2008). Binge eating disorder and body uneasiness. Psihologijske Teme, 17(2), 287-312.

Edwards, S. \& Launder, C. (2000). Investigating Muscularity Concerns in Male Body Image: Development of the Swansea Muscularity Attitudes Questionnaire. International Journal of Eating Disorders. 28(1), 120-124.

Feldman, M. B. \& Meyer, I. H. (2007). Eating disorders in diverse lesbian, gay, and bisexual populations. International Journal of Eating Disorders, 40(3), 218-226.

Feldman, M. B. \& Meyer, I. H. (2010). Comorbidity and age of onset of eating disorders in gay men, lesbians, and bisexuals. Psychiatry Research, 180(2-3), 126131.

First, M. B., Spitzer, R. L., Gibbon, M., \& Williams, J. B. W. (1996). Structured Clinical Interview for DSM-IV Axis I Disorders: Patient Version (SCID-I/P). Washington, D.C.: American Psychiatric Press.

Fitzgibbon, M. L., Sánchez-Johnsen, L., \& Martinovich, Z. (2003). A test for the continuity perspective across bulimic and binge eating pathology. International Journal of Eating Disorders, 34(1), 83-97.

Galanti, K., Gluck, M. E., \& Geliebter, A. (2007). Test meal intake in obese binge eaters in relation to impulsivity and compulsivity. International Journal of Eating Disorders, 40(8), 727-732.

García-Camba, E. (2001). Avances en trastornos de la conducta alimentaria. Anorexia nerviosa, bulimia nerviosa y obesidad. Barcelona: Masson.

Geliebter, A., Hassid, G., \& Hashim, S. A. (2001). Test meal intake in obese binge eaters in relation to mood and gender. International Journal of Eating Disorders, 29(4), 488-494.

Gormally, J., Black, S., Datson, S., \& Rardin, D. (1982). The assessment of binge eating severity among obese persons. Addictive Behaviors, 7(1), 47-55.

Grilo, C. M. \& Masheb, R. M. (2004). Night-time eating in men and women with binge eating disorder. Behaviour Research and Therapy, 42(4), 397-407.

Grilo, C. M. \& Masheb, R. M. (2005). Correlates of Body image dissatisfaction in treatment-seeking men and women with binge eating disorder. International Journal of Eating Disorders, 38(2), 162-166.

Grilo, C. M, White, M. A., \& Masheb, R. M. (2009). DSM-IV psychiatric disorder comorbidity and its correlates in binge eating disorder. International Journal of Eating Disorders, 42(3), 228-234.

Grucza, R. A., Przybeck, T. R., \& Cloninger, C. R. (2007). Prevalence and correlates of binge eating disorder in a community sample. Comprehensive Psychiatry, 48(2), 124-131.

Hay, P. (1998). The epidemiology of eating disorder behaviors: An Australian community-based survey. International Journal of Eating Disorders, 23(4), 371-382.

Hefferman, K. (1994). Sexual orientation as a factor in risk for binge eating and bulimia nervosa: a review. International Journal of Eating Disorders, 16(4), 335-347.

Hodges, E. L., Stellefson, E. J., Jarrell, M. P., Cochrane, C. E., \& Brewerton, T. D. (1999). Eating disorder pathology in a culinary arts school. Eating Disorders: The Journal of Treatment and Prevention, 7(1), 43-50.

Hoek, H. W. \& van Hoeken, D. (2003). Review of the prevalence and incidence of eating disorders. International Journal of Eating Disorders, 34(4), 383-396.

Hrabosky, J. I., White, M. A., Masheb, R. M., \& Grilo, C. M. (2007). Physical activity and its correlates in treatment-seeking obese patients with binge eating disorder. International Journal of Eating Disorders, 40(1), 72-76.

Hsu, L. K. G., Mulliken, B., McDonagh, B., Krupa, S., Rand, W., Fairburn, C. G., ... Roberts, S. (2002). Binge eating disorder in extreme obesity. International Journal of Eating Disorders, 26(10), 1398-1403.

Hudson, J. I., Hiripi, E., Pope, H. G., \& Kessler, R. C. (2012). The Prevalence and Correlates of Eating Disorders in the National Comorbidity Survey Replication. Biological Psychiatry, 72(2), 164.

Johnsen, L., Gorin, A., Stone, A., \& Grange, D. (2003). Characteristics of binge eating among women in the community seeking treatment for binge eating or weight loss. Eating Behaviors, 3(4), 295-305.
Kolotkin, R. L., Westman, E. C., Ostbye, T., Crosby, R. D., Eisenson, H. J., \& Binks, M. (2004). Does Binge Eating Disorder Impact Weight-Related Quality of Life? Obesity Research, 12(6), 999-1005.

Leit, R. A., Gray, J. J., \& Pope, H. G. (2002). The media's representation of the ideal male body: A cause for muscle dysmorphia? International Journal of Eating Disorders, 31(3), 334-338.

Linde, J. A., Jeffery, R. W., Levy, R. L., Sherwood, N. E., Utter, J., Pronk, N. P., \& Boyle, R. G. (2004). Binge eating disorder, weight control self-efficacy, and depression in overweight men and women. International Journal of Obesity, 28(3), 418-425.

Litwack, S. D., Mitchell, K. S., Sloan, D. M., Reardon, A. F., \& Miller, M. W. (2014). Eating disorder symptoms and comorbid psychopathology among male and female veterans. Gen Hosp Psychiatry. 36(4), 406-410.

Lundgren, J. D, Rempfer, M. V, Brown, C. E, Goetz, J., \& Hamera, E. (2010). The prevalence of night eating syndrome and binge eating disorder among overweight and obese individuals with serious mental illness. Psychiatry Research, 175(3), 233-236.

Marcus, M. D. (1997). Adapting treatment for patients with binge Eating Disorders. In D. M. Garner \& P. E. Garfinkel (Eds.), Handbook of treatment for eating disorders (2a ed., pp. 484-483). New York: The Guilford Press.

Masheb, R. M. \& Grilo, C. M. (2006a). Eating patterns and breakfast consumption in obese patients with binge eating disorder. Behaviour Research and Therapy, 44(11), 1545-1553.

Masheb, R. M. \& Grilo, C. M. (2006b). Emotional overeating and its associations with eating disorder psychopathology among overweight patients with binge eating disorder. International Journal of Eating Disorders, 39(2), 141-146.

Neumark-Sztainer, D., Sherwood, N. E., French, S. A., \& Jeffery, R. W. (1999). Weight control behaviors among adult men and women: cause for concern? Obesity Research. 7(2), 179-188.

Neumark-Sztainer, D., Wall, M., Story, M., \& Sherwood, N. E. (2009). Five-year longitudinal predictive factors for disordered eating in a population-based sample of overweight adolescents: implications for prevention and treatment. International Journal of Eating Disorders, 42(7), 664-672.

Nicdao, E. G., Hong, S., \& Takeuchi, D. T. (2007). Prevalence and correlates of eating disorders among Asian Americans: Results from the National Latino and Asian American Study. International Journal of Eating Disorders, 40(S3), s22-s26.

Ramacciotti, C. E., Coli, E., Passaglia, C., Lacorte, M., Pea, E., \& Dell'Osso, L. (2000). Binge eating disorder: prevalence and psychopathological features in a clinical sample of obese people in Italy. Psychiatry Research, 94(2), 131138.

Reas, D. L., Masheb, R. M., \& Grilo, C. M. (2004). Appearance vs. Health Reasons for Seeking Treatment Among Obese Patients with Binge Eating Disorder. Obesity Research, 12(5), 758-760.

Reas, D. L., Grilo, C. M., Masheb, R. M., \& Wilson, G. T. (2005). Body Checking and Avoidance in Overweight Patients with Binge Eating Disorder. International Journal of Eating Disorders, 37(4), 342-346.

Reas, D. L. \& Grilo, C. M. (2007). Timing and Sequence of the Onset of Overweight, Dieting, and Binge Eating in Overweight Patients with Binge Eating Disorder. International Journal of Eating Disorders, 40(2), 165-170.

Robertson, D. N. \& Palmer, R. L. (1997). The prevalence and correlates of binge eating in British community sample of women with history of obesity. International Journal of Eating Disorders, 22(3), 323-327.

Roehrig, M., Masheb, R. M., White, M. A., \& Grilo, C. M. (2009). Dieting frequency in obese patients with binge eating disorder: Behavioral and metabolic correlates. Obesity, 17(4), 689-697.

Spitzer, R. L., Devlin, M., Walsh, B. T., Hasin, D., Wing, R., Marcus, M., ... Nonas, C. (1992). Binge eating disorder: A multisite field trial of the diagnostic criteria. International Journal of Eating Disorders, 11(3), 191-203.

Spitzer, R. L., Yanovski, S., Wadden, T., Wing, R., Marcus, M., Stunkard, A., ... Horne, R. L. (1993). Binge eating disorders: Its further validation in a multisite study. International Journal of Eating Disorders, 13(2), 137-153.

Striegel-Moore, R. H., Wilson, G. T., Wilfley, D. E., Elder, K. A., \& Brownell, K. D. (1998). Binge eating in an obese community sample. International Journal of Eating Disorders, 23(1), 27-37. 
Stunkard, A. J. (1959). Eating patterns and obesity. Psychiatric Quarterly, 33(2), 284-292.

Tanofsky, M. B., Wilfley, D. E., Spurrell, E. B., Welch, R., \& Brownell K. D. (1997). Comparison of men and women with binge eating disorder. International Journal of Eating Disorders, 21(1), 49-54.

Telch, C. F. \& Agras, W. S. (1994). Obesity, binge eating and psychopathology:Are they related?. International Journal of Eating Disorders, 15(1), 53-61.

Vervaet, M., van Heeringen, C., \& Audenaert, K. (2004). Binge Eating Disorder and Non-purging Bulimia: More Similar than Different?. European Eating Disorders Review, 12(1), 27-33.

Villagómez, L., Cortés, J., Barrera, E., Saucedo, D., \& Alcocer, L. (2003). Comorbilidad de la obesidad con los trastornos de la conducta alimentaria. Revista de Investigación Clínica, 55(5), 535-545.
Weltzin, T. E., Weisensel, N., Franczyk, D., Burnett, K., Klitz, C., \& Bean, P. (2005) Eating disorders in men: Update. The Journal of Men's Health \& Gender, 2(2), 186-193.

Williamson, D. A. \& Martin, C. K. (1999). Binge eating disorder: A review of the literature after publication of DSM-IV. Eating and Weight Disorders, 4(3), 103 114.

Womble, L. G., Williamson, D. A., Martin, C. K., Zucker, N. L., Thaw, J. M., Netemeyer, R., ... Greenway, F. L. (2001). Psychosocial variables associated whit binge eating in obese males and females. International Journal Eating Disorders, 30(2), 217-221. 